UNCLASSIEIED

ISC-382

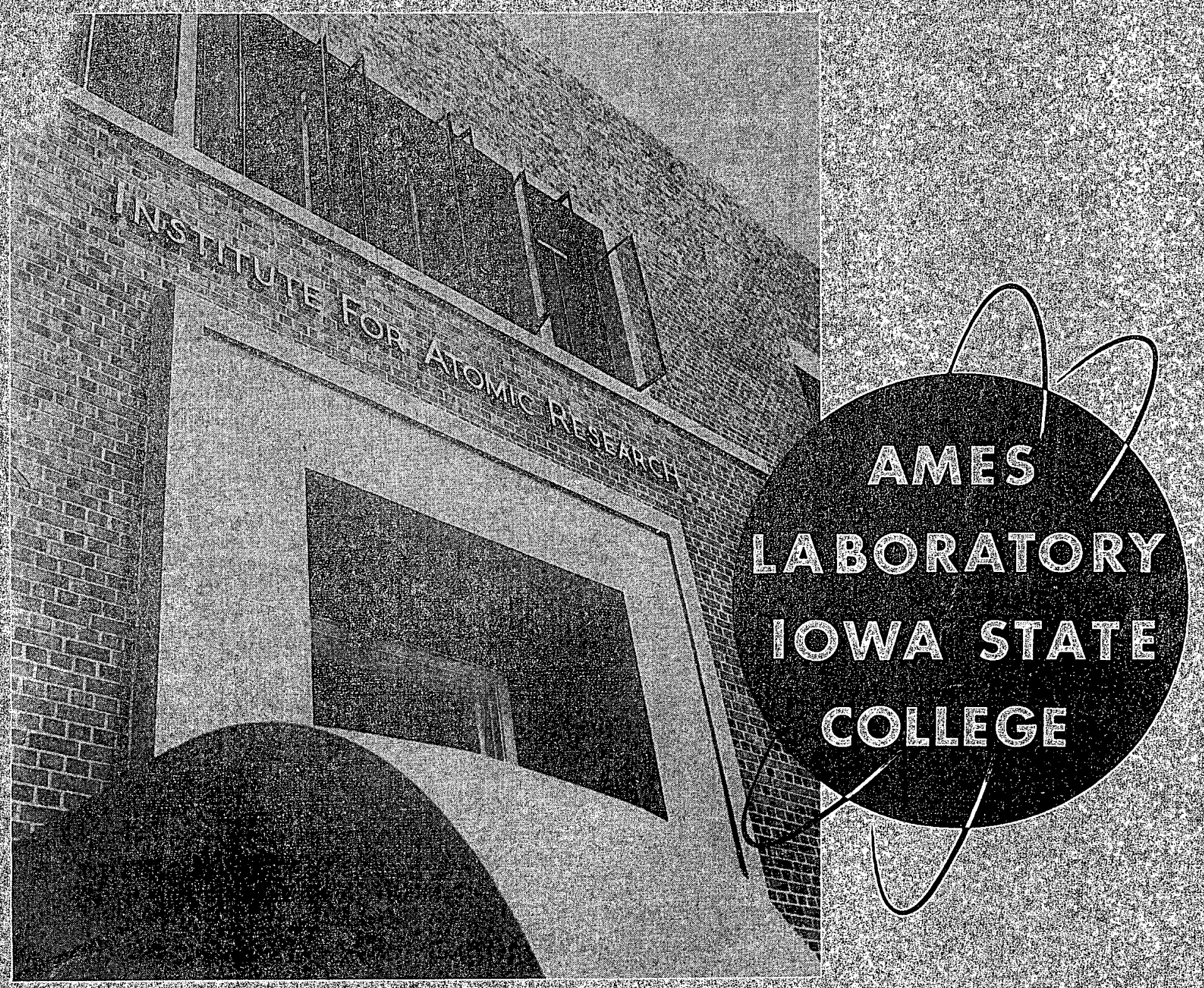

TITRIMETRIC DETERMINATION OF ZIRCONHUM

UNGLASSIFIED 


\section{DISCLAIMER}

This report was prepared as an account of work sponsored by an agency of the United States Government. Neither the United States Government nor any agency Thereof, nor any of their employees, makes any warranty, express or implied, or assumes any legal liability or responsibility for the accuracy, completeness, or usefulness of any information, apparatus, product, or process disclosed, or represents that its use would not infringe privately owned rights. Reference herein to any specific commercial product, process, or service by trade name, trademark, manufacturer, or otherwise does not necessarily constitute or imply its endorsement, recommendation, or favoring by the United States Government or any agency thereof. The views and opinions of authors expressed herein do not necessarily state or reflect those of the United States Government or any agency thereof. 


\section{DISCLAIMER}

Portions of this document may be illegible in electronic image products. Images are produced from the best available original document. 
$\underline{\mathrm{U}} \underline{\mathrm{N}} \underline{\mathrm{C}} \underline{\mathrm{L}} \underline{\mathrm{A}} \underline{\mathrm{S}} \underline{\mathrm{S}} \underline{\mathrm{I}} \underline{\mathrm{F}} \underline{\mathrm{I}} \underline{\mathrm{E}} \underline{\mathrm{D}}$

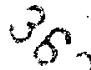

ISC -382

$\because \mathrm{U} N I T E D$

$S$ T A T E S

A $T \circ M I C$

E N E R G Y

C O M M S S I O N

\section{TITRIMETRIC DETERMINATION OF ZIRCONIUM}

By

James S. Fritz and Myron O. Fulda

July 28, 1953

Ames Laboratory

at

Iowa state college

F. H. Spedding, Director

Contract $\mathrm{W}-7405$ eng -82

$\underline{\mathrm{U}} \underline{\mathrm{N}} \underline{\mathrm{C}} \underline{\mathrm{L}} \underline{\mathrm{A}} \underline{\mathrm{S}} \underline{\mathrm{S}} \underline{\mathrm{I}} \underline{\mathrm{F}} \underline{\mathrm{I}} \underline{\mathrm{E}} \underline{\mathrm{D}}$ 
This report is distributed according to the category ChemistryGeneral as listed in M-3679, April 15, 1953. 
TABLE OF CONTENTS

Page

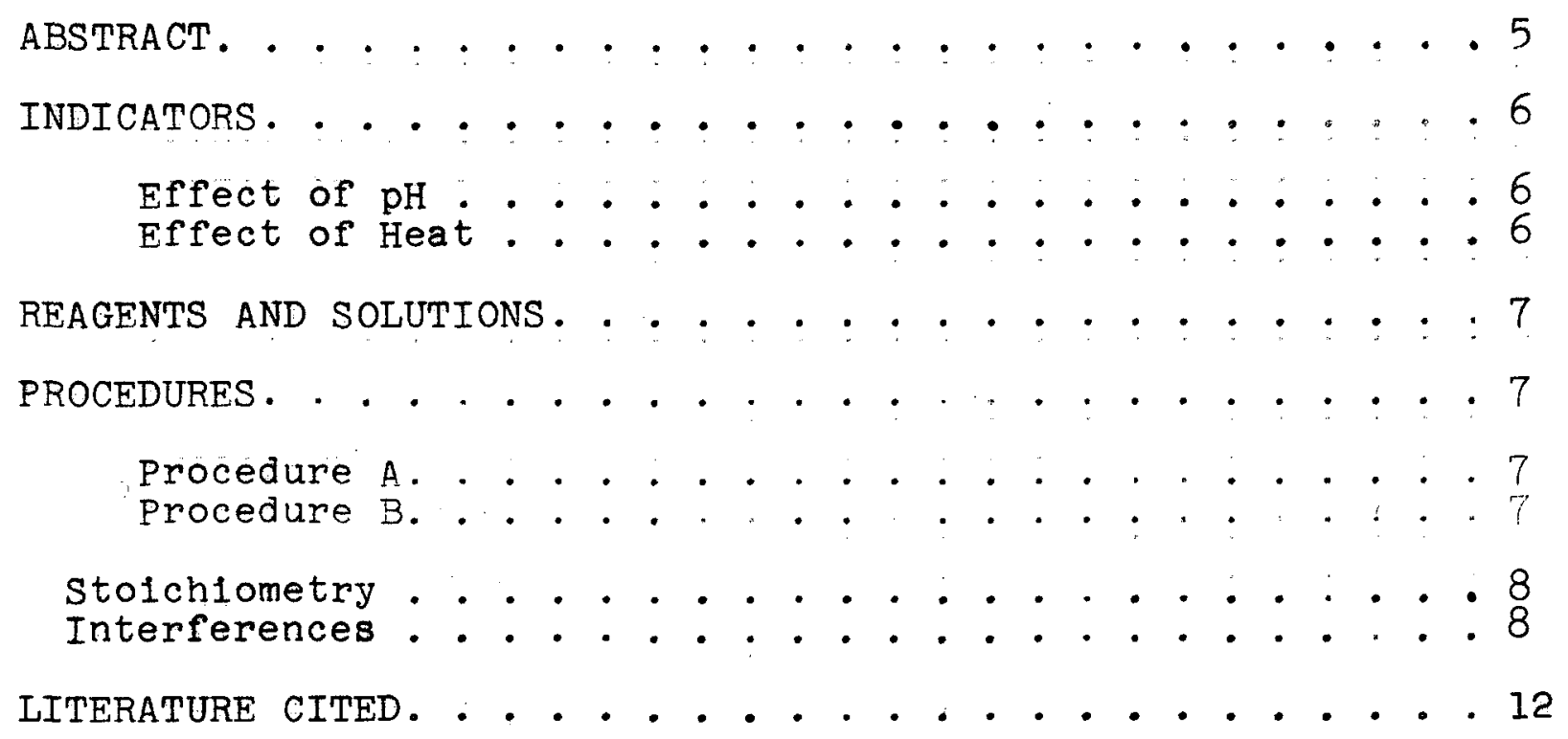


4 


\title{
TITRIMETRIC DETERMINATION OF ZIRCONIUM
}

James S. Fritz and Myron O. Fulda

\author{
ABSTRACT
}

Macro amounts of zirconium are usually determined gravimetrically or by titrimetric means following quantitative isolation of a precipitate. This is time-consuming. This paper describes a quick, direct titrimetric method for zirconium. The titration is carried out in acid solution with Versene (disodium dihydrogen ethylenediaminetetraacetate), a stable, soluble complex being formed. A visual indicator gives a sharp end point. Iron, thorium, mol-ybdenum and bismuth constitute important interferences, but most other metals do not affect the results. Tin and titanium. reduce the sharpness of the end point but do not otherwise interfere. This method should be applicable to many specific problems without modification. It also constitutes a new approach to the determination of zirconium in more difficult samples.

Most of the recent progress in analytical methods for macro amounts of zirconfum has been due to the development of organic precipitants such as cupferron, mandelic acld and arsonic acids. of these, mandelic acid and its derivatives $(6,8,9)$ are probably the most successful. They possess excellent selectlvity for zirconium and under proper conditions form precipitates of definite composition.

Because gravimetric methods are t1me-consuming, a rapid volumetric determination of zirconlum would be desirable. Kolthoff and Johnsion (7) have reported an amperometric titration of zirconium, thorium, tin and uranium with m-nitrophenylarsonic acld. White (10) developed a titrimetric method for zirconium following the quantitative isolation of zirconium mandelate. "Dhar and Das Gupta (1) determined zirconium by either colorimetric or titrimetric means following precipitation with oxalohydroxamic acid. The direct titration of thorium in acid solution with ethylenediaminetetraacetic acid (Versene) using Alizarin Red $S$ indicator has recently been reported (2). Zirconium interferes in this titration but cannot itself be titrated by the thorium procedure. Now, however, new indicators have been found which permit the rapid and accurate titration of zirconlum with versene. The method proposed is selective and should be of use in numerous cases. 


\section{INDICATORS}

The general reactions involved in the titration are as follows:

$$
\begin{aligned}
& \mathrm{Zr}(\mathrm{IV})+\mathrm{H}_{2} \text { Vers }^{-2}=\mathrm{Zr} \text { Vers }+2 \mathrm{H}^{+} \\
& \operatorname{ZrIn}_{\mathrm{n}}+\mathrm{H}_{2} \text { Vers }^{-2}=\mathrm{Zr} \text { Vers }+\mathrm{nHIn}
\end{aligned}
$$

After the bulk of the zirconium has reacted according to (1), the highly colored zirconium-indicator complex is destroyed (reaction 2), marking the end point. In addition to being highly colored, the zirconium-1ndicator complex must be less stable than the zirconlum-Versene complex. Further, reaction (2) must be fairly rapid so that the end point will not be over-run.

Several indicators were tried. Allzarin Red $S$ gives a brililant color with zirconium and has been used for colorimetric determination of zirconium (5). "This indicator is, however, useless for the versene titration of zirconlum because of the very slow reaction of the zirconium-1ndicator complex with versene. Slow equilibrium is also encountered with carminic acid indicator. Chloranilic acid requires too low a pH and Chrome Azurol $S$ gives an end point which is falrly sharp, but somewhat lacking in vividness. Both Alizarol Cyanone RC and Erlochromecyanine give sharp and vivid end points. The Alizarol Cyanone end point is often slow if a direct versene titration is attempted, but is fast if a slight excess of Versene is added and back-titrated hot with standard zirconium. Elther direct or back-titration is possible with Eriochromecyanine, but the end point in the direct titration should not be approached too rapidly.

Effect of $\mathrm{pH}$

W1th either Alizarol Cyanone or Eriochromecyanine indicator, satisfactory end points can be obtained in the $\mathrm{pH}$ range 1.0 to 2.0. Best accuracy is obtained, however, if the final $p H$ is between 1.3 and 1.5 . Results for zirconium are high above pH 1.5 and low below $\mathrm{pH} 1.3$.

Effect of Heat

Heating the solution to 70 to $90^{\circ} \mathrm{C}$ speeds the reaction and permits a rapid back-titration of excess Versene with zirconium. A direct titration in hot solution is not however, recommended due to the possibility of hydrolyzing the zirconium. In one experiment where the zirconium solution was heated for 15 minutes before titration, no end point was observed even with $100 \%$ excess Versene. Probabiy part of the zirconium precipitates and the Jelly-like precipitate absorbs the indicator so strongly that no end point is possible. 


\section{REAGENTS AND SOLUTIONS}

\section{Alizarol Cyanone RC}

$0.4 \%$ aqueous solution.

Eriochromecyanine RC

$0.4 \%$ aqueous solution.

Hafnium Chloride

$0.5 \mathrm{M}$ solution in $5 \%$ hydrochloric acid, standardized by evaporation and ignition to the oxide. The zirconium content is $2.1 \%$ by weight as determined by spectrographic analysis.

Thorlum Nitrate

$0.5 \mathrm{M}$ solution prepared and standardized as outlined by Fritz and Ford (2)。

Versene

$0.5 \mathrm{M}$ solution prepared from the disodium salt of ethylenediaminetetraacetic acid. This solution was standardized against calcium carbonate (4) or against pure zinc metal (3)。

Zirconium Chloride

$0.5 \mathrm{M}$ solution in $5 \%$ hydrochloric acid, standardized by evaporation and ignition to the oxide. The zirconyl chloride used to prepare this solution contained $100 \mathrm{ppm}$ or less hafnium.

\section{PROCEDURES}

Procedure A

The zirconium concentration of the solution taken for analysis should be about 0.003 to $0.005 \mathrm{M}$. Adjust the $\mathrm{pH}$ to 1.4 , add 2 drops of Eriochromecyanine indicator and titrate with $0.05 \mathrm{M}$ Versene to disappearance of a pink color.

Procedure B

Using either Eriochromecyanine or Alizarol Cyanone indicator, follow procedure $A$ but titrate rapidly and add a slight excess of Versene. Adjust the $\mathrm{pH}$ to 1.4 , heat the solution almost to bolling and back-titrate with $0.05 \mathrm{M}$ zirconium chloride to the first permanent pink color. 


\section{CAICULATIONS}

$$
\begin{array}{ll}
\mathrm{mg} \cdot \mathrm{Zr}=91.2 \mathrm{VM} & \text { (Procedure } \mathrm{A}) \\
\mathrm{mg} \cdot \mathrm{Zr}=91.2 \Lambda\left(\mathrm{V}_{\mathrm{V}} \mathrm{M}_{\mathrm{V}}\right)-\left(\mathrm{V}_{\mathrm{z}} \mathrm{M}_{\mathrm{z}}\right) 7 & \text { (Procedure } \mathrm{B})
\end{array}
$$

where:

$$
\begin{aligned}
& V=\text { volume in } \mathrm{ml} . \\
& M=\text { molarity } \\
& \text { subscript } \mathrm{v}=\text { Versene } \\
& \text { Subscript } \mathrm{z}=\text { zirconium. }
\end{aligned}
$$

Stoichiometry

Since aqueous solutions of zirconium show a very great tendency to polymerize, there appeared to be some doubt as to whether any direct titrimetric method for zirconium could be made stolchiometric. Test for stoichiometry was made by titrating aliquots of a zirconium chloride solution which had been standardized both by evaporation and ignition, and by mandelic acid precipitation and ignition. The Versene used to titrate the zirconium was standardized against calcium carbonate (4) and against very pure zinc metal (3). Stoichiometric results were obtained only when a correction was applied for the approximately $2 \%$ hafnium present in the zirconium solution, assuming that the hafnium was titrated with the zirconium. The hafnium content of the solution was determined independently by our spectrographic laboratory. To further check the stolchiometry, a standard zirconium chloride solution containing $100 \mathrm{ppm}$ or less of hafnium was titrated with standard Versene. Results given in Table 1 show that at least within ordinary titration error the method is stoichiometric, a $1: 1$ zirconium-Versene complex being formed.

\section{Interferences}

Table 2 lists the interfering and non-interfering cations. Copper interferes in a direct titration but no interference is noted if excess versene is added and the solution heated several minutes before back-titration. on the other hand if aluminum is present, Procedure A must be followed. This is because once the zirconium-indicator complex has been broken by adding excess Versene, the aluminum is free to react with the indicator. The direct titration succeeds because the aluminum reacts slowly with the indicator, especially at room temperature. The fact that ions such as $\mathrm{Cu}, \mathrm{Ni}$ and $\mathrm{Pb}$. do not interfere although their versene complexes are very stable ( $\log \mathrm{K}$ formation is around 18), means that both the $\mathrm{zIr}-$ conlum-Versene and the zirconium-indicator complexes are very strong. 
Table 1

Titration of Zirconium by Procedure A

\begin{tabular}{|c|c|c|c|}
\hline $\begin{array}{l}\text { Zr Taken } \\
\text { mg. }\end{array}$ & $\begin{array}{c}\text { Theoretical } \\
\text { Versene } \\
\text { ml. }\end{array}$ & $\begin{array}{c}\text { Actual } \\
\text { versene } \\
\text { m } 1\end{array}$ & $\begin{array}{c}\text { Diff. } \\
\text { ml. }\end{array}$ \\
\hline 22.8 & 5.24 & 5.24 & \pm 0.00 \\
\hline 22.8 & 5.24 & 5.24 & \pm 0.00 \\
\hline 22.8 & 5.24 & 5.25 & +0.01 \\
\hline 22.8 & 9.47 & 9.47 & \pm 0.00 \\
\hline 22.8 & 9.47 & 9.48 & +0.01 \\
\hline 22.8 & 9.47 & 9.49 & +0.02 \\
\hline
\end{tabular}

Interference by tin (IV) is avolded by adding excess Versene to a rather acidic sample ( $\mathrm{pH}$ about 0.5 ) then back-titrating at room temperature with zirconium using Eriochromecyanine indicator. Titanium (IV) interference is avolded by a similar procedure but Versene must be added in excess of the amount equivalent to the combined zirconium and titanium. The solution is then heated almost to bolling and back-titrated with zirconium. The presence of either tin or titanium decreases the sharpness of the end point.

No Interference is caused by perchlorate, chloride, nitrate or acetate. As might be expected such anions as phosphates, molybdate, sulfate, fluoride and oxalate do interfere ser1ously.

$\mathrm{Hf}$ and $\mathrm{Th}$ interferences were investigated quantitatively. Mixtures of known amounts of zirconium-hafnium and zirconium-thorium were prepared and titrated. The results given in Table 3 confirm the quantitative nature of the thorlum and hafnium interferences. It is possible that zirconium-1ron mixtures can also be titrated quantitatively. 
Table ?

Interference Study

\begin{tabular}{|c|c|c|c|c|c|}
\hline \multirow[b]{2}{*}{ Ion } & \multirow[b]{2}{*}{ added } & \multicolumn{2}{|c|}{ Procedure $A$} & \multicolumn{2}{|c|}{ Procedure E } \\
\hline & & $\begin{array}{c}\text { Versene, } \\
\text { theory } \\
\text { ml. }\end{array}$ & $\begin{array}{c}\text { Versene, } \\
\text { actual } \\
\text { ml. }\end{array}$ & $\begin{array}{c}\text { Versene, } \\
\text { theory } \\
\text { ml. }\end{array}$ & $\begin{array}{c}\text { Versene, } \\
\text { actual } \\
\text { ml. }\end{array}$ \\
\hline & $\begin{array}{l}\mathrm{Ag}^{+} \\
\mathrm{Al}^{+++} \\
\mathrm{Ba}^{++} \\
\mathrm{Be}^{++}\end{array}$ & $\begin{array}{l}5.24 \\
5.24 \\
5.24 \\
5.24\end{array}$ & $\begin{array}{l}\text { Interferes } \\
5.24 \\
5.24 \\
5.23\end{array}$ & $\begin{array}{l}5.21 \\
5.21 \\
5.21 \\
5.21\end{array}$ & $\begin{array}{l}5.25 \\
\text { interferes } \\
5.20 \\
5.25\end{array}$ \\
\hline & $\begin{array}{l}\mathrm{Bl}^{+++} \\
\mathrm{Ca}^{++} \\
\mathrm{Cd}^{++} \\
\mathrm{Ce}^{+++}\end{array}$ & $\begin{array}{l}5.24 \\
5.24 \\
-\overline{5} .24\end{array}$ & $\begin{array}{l}\text { Interferes } \\
5.24 \\
5.24\end{array}$ & $\begin{array}{l}5.21 \\
5.21 \\
5.21 \\
3.50\end{array}$ & $\begin{array}{l}\text { interferes } \\
5: 20 \\
5: 21 \\
3.51\end{array}$ \\
\hline$\therefore:$ & $\begin{array}{l}\mathrm{CO}_{++}^{+} \\
\mathrm{Cr}^{++} \\
\mathrm{Cu}_{++}^{+} \\
\mathrm{Cu}^{+}\end{array}$ & $\begin{array}{l}5.24 \\
5.24 \\
5.24 \\
--\end{array}$ & $\begin{array}{l}5.26 \\
5.22 \\
\text { interferes }\end{array}$ & $\begin{array}{l}5.21 \\
3.50 \\
3.50 \\
4.50\end{array}$ & $\begin{array}{l}5.20^{*} \\
3.50 \\
3.51^{*} \\
4.51^{*}\end{array}$ \\
\hline & $\begin{array}{l}\mathrm{Fe}^{+t} \\
\mathrm{Fe}^{++} \\
\mathrm{Fe}^{+++} \\
\mathrm{Hg}^{++}\end{array}$ & $\begin{array}{l}5.24 \\
5.24 \\
5.24 \\
5.24\end{array}$ & $\begin{array}{l}5.28 \\
5.35 \\
\text { interferes } \\
5.24\end{array}$ & $\begin{array}{l}5.21 \\
-- \\
5.21 \\
4.17\end{array}$ & $\begin{array}{l}\text { Interferes } \\
-- \\
\text { interferes } \\
4.18\end{array}$ \\
\hline & $\begin{array}{l}\mathrm{K}^{+} \\
\mathrm{La}^{+++} \\
\mathrm{LI}^{+} \\
\mathrm{Mg}^{++}\end{array}$ & $\begin{array}{l}5.24 \\
5.24 \\
5.24 \\
5.24\end{array}$ & $\begin{array}{l}5.22 \\
5.24 \\
5.22 \\
5.22\end{array}$ & $\begin{array}{l}4.50 \\
3.50 \\
5.21 \\
5.41\end{array}$ & $\begin{array}{l}4.50 \\
3.51 \\
5.20 \\
5.39\end{array}$ \\
\hline & $\begin{array}{l}\mathrm{Mn}^{+4} \\
\mathrm{Mo}^{++4} \\
\mathrm{MoO}_{4}= \\
\mathrm{Na}^{+4}\end{array}$ & $\begin{array}{l}5.24 \\
5.24 \\
5.24 \\
5.24\end{array}$ & $\begin{array}{l}5.22 \\
\text { interferes } \\
\text { Interferes } \\
5.24\end{array}$ & $\begin{array}{l}5.41 \\
5.41 \\
5.41 \\
5.69\end{array}$ & $\begin{array}{l}5.41 \\
\text { interferes } \\
\text { interferes } \\
5.70\end{array}$ \\
\hline 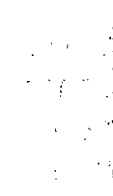 & $\begin{array}{l}\mathrm{NI}^{++} \\
\mathrm{NH}_{4+}^{+} \\
\mathrm{Pb}_{++} \\
\mathrm{Sb}^{+4}\end{array}$ & $\begin{array}{l}5.24 \\
5.24 \\
5.24 \\
5.24\end{array}$ & $\begin{array}{l}5.36 \\
5.24 \\
5.22 \\
\text { interferes }\end{array}$ & $\begin{array}{l}5.21 \\
5.21 \\
5.21 \\
5.21\end{array}$ & $\begin{array}{l}5.25,5.32 \\
5.21 \\
5.18 \\
\text { interferes }\end{array}$ \\
\hline & $\begin{array}{l}\mathrm{Sr}^{++} \\
\mathrm{Sn}^{++} \\
\mathrm{Sn}^{++++} \\
\mathrm{TI}^{+++}\end{array}$ & $\begin{array}{l}5.24 \\
5.24 \\
5.24 \\
5.24\end{array}$ & $\begin{array}{l}5.23 \\
\text { interferes } \\
\text { interferes } \\
\text { interferes }\end{array}$ & $\begin{array}{l}5.21 \\
5.21 \\
5.41 \\
5.35\end{array}$ & $\begin{array}{l}5.23 \\
\text { interferes } \\
5.38 \\
\text { interferes }\end{array}$ \\
\hline & $\begin{array}{l}\mathrm{TI}_{++++} \\
\mathrm{T} \mathrm{T}_{++++} \\
\mathrm{Th}^{+++4} \\
\mathrm{UO}_{2}^{+4}\end{array}$ & $\begin{array}{l}5.24 \\
-2 \\
5.24 \\
5.24\end{array}$ & $\begin{array}{l}\text { interferes } \\
\text {-- } \\
\text { interferes } \\
5.24\end{array}$ & $\begin{array}{l}5.41 \\
5.41 \\
5.41 \\
3.50\end{array}$ & $\begin{array}{l}5.37 \\
5.38 \\
\text { interferes } \\
3.50\end{array}$ \\
\hline
\end{tabular}

* Heated 15 minutes before back-titration.

* Approximately equimolar to the zirconium concentration. 
Table 2 (Continued)

\begin{tabular}{|c|c|c|c|c|}
\hline Ion added ${ }^{* *}$ & $\begin{array}{c}\text { Proce } \\
\text { Versene, } \\
\text { theory } \\
\mathrm{ml} .\end{array}$ & $\begin{array}{c}\text { Uure A } \\
\text { Versene, } \\
\text { actual } \\
\text { ml. }\end{array}$ & $\begin{array}{l}\text { Proce } \\
\text { Versene, } \\
\text { theory } \\
\text { ml. }\end{array}$ & $\begin{array}{c}\text { Aure } B \\
\text { Versene, } \\
\text { actual } \\
\text { m } 1 .\end{array}$ \\
\hline $\begin{array}{l}\mathrm{VO}^{++} \\
\mathrm{VO}_{3-}^{-} \\
\mathrm{VO}_{3-}^{-} \\
\mathrm{WO}_{4}=\end{array}$ & $\begin{array}{l}5.24 \\
5.24 \\
-2.24\end{array}$ & $\begin{array}{l}5.33 \\
5.21 \\
\text { interferes }\end{array}$ & $\begin{array}{l}4.17 \\
5.21 \\
5.21 \\
5.23\end{array}$ & $\begin{array}{l}4.18 \\
5.21 \\
5.19 \\
\text { interferes }\end{array}$ \\
\hline $\begin{array}{l}\mathrm{Zn}^{++} \\
\mathrm{AC}^{-}\end{array}$ & $\begin{array}{l}5.24 \\
5.41\end{array}$ & $\begin{array}{l}5.24 \\
5.38\end{array}$ & $\begin{array}{l}5.21 \\
4.17\end{array}$ & $\begin{array}{l}5.23 \\
4.21\end{array}$ \\
\hline $\begin{array}{l}\mathrm{F}^{-} \\
\text {Mandelate }\end{array}$ & $\begin{array}{l}5.41 \\
5.24\end{array}$ & $\begin{array}{l}\text { Interferes } \\
5.25\end{array}$ & $\begin{array}{l}5.21 \\
4.17\end{array}$ & $\begin{array}{l}\text { interferes } \\
4.18\end{array}$ \\
\hline $\begin{array}{l}\mathrm{SO}_{4}= \\
\text { Tartrate }\end{array}$ & $\begin{array}{l}5.41 \\
5.24\end{array}$ & $\begin{array}{l}\text { interferes } \\
\text { interferes }\end{array}$ & $\begin{array}{l}5.21 \\
5.21\end{array}$ & $\begin{array}{l}\text { Interferes } \\
\text { Interferes }\end{array}$ \\
\hline
\end{tabular}

Table 3

Titration of Mixtures

Theoretical Versene

$\mathrm{ml}$.
Actual Versene ml.
$\mathrm{Zr}$
3.66
Th
2.59
Sum
6.25
$6.26,6.22,6.22$
$\mathrm{Zr}$
2.71
$\mathrm{Hf}$
$\underline{2.64}$
Sum
5.35
$5.32,5.33,5.32$ 
1. Dhar, S. K. and Das Gupta, A. K., J. Sc1. Industr. Res. India,

2. Fritz, J. S...and Ford, J. J., Anal. Chem... (In Press).

3. Fritz, J. S., Ford, J. J, and Lane, W. J., ISC report (In Press).

4. Goetz, C. A., Loomis, T. C. and Dlehl, H., Anal. Chem. 22,
798 (1950).

5. Green, D. E., Anal. Chem., 20, 370 (1948).

6. Hahn, R., Anal. Chem., 21, 1579 (1949).

7. Kolthoff, I. M. and Johnson, R. A., J. Electrochem. Soc., 98,
138 (195i).

8. Kummins, C. A., Ana 1. Chem., 19, 376 (1947).

9. Oesper, R. E. and Klingenberg, J. J., Anal. Chem., 21, 1509

10. White, J. C., Paper A-21, Anal. Information Meeting, Oak Ridge National Laboratory, May, 1953. 